\title{
Laman dan Reputasi Lembaga Dalam Membangun Komunikasi dengan Stakeholders
}

\author{
Mukaromah, Devi Purnama Sari \\ (mukaromahoke@gmail.com, devi.purnamasari9@gmail.com) \\ (Program Studi Ilmu Komunikasi, Fakultas Ilmu Komputer, Universitas Dian Nuswantoro)
}

\begin{abstract}
Page is one of the means of communication for a institute that can not be inevitable in the current development of information technology today. The purpose of this study was to find out how the reader's perception of the website educational institutions in communicating their vision and mission. Using the method of qualitative descriptive study the research object Udinus page readers Semarang who are stakeholders. The results of the study reflect on the reader's perception of the page that conveys that reflect Udinus page as a page that is engaged in the field of education with the reputation of the institution which is prominent in the field of information technology. There needs to be improvement in conveying information in the field of entrepreneurship because the eyes of the readers who become informants in this research, news and events related to entrepreneurship has not been managed properly.
\end{abstract}

Keywords: Page, Reputation, Perception

\section{Pendahuluan}

Kemajuan teknologi memunculkan adanya media baru. Media baru adalah media yang memanfaatkan jaringan internet dalam aktivitasnya yang menitikberatkan pada kecepatan informasi bagi pengunggahnya dibanding dengan media konvensional seperti surat kabar ataupun televisi. Media baru ini sering disebut dengan media online. Adanya media baru dapat digunakan oleh pekerja humas (Public Relations Officer) untuk melaksanakan fungsinya dalam berkomunikasi, memberikan informasi dengan stakeholdernya.

Salah satu bentuk media baru adalah website atau laman. Website adalah situs internet yang dapat diakses melalui jaringan Word Wide Web yang mana website ini terdiri dari halaman yang dilengkapi dengan animasi gambar dan berinteraksi dengan data (Kadir, 2003: 386).

Berdasarkan data dari Kementrian Komunikasi dan Informatika yang diunggah dalam lamannya menyampaikan bahwa hingga tahun 2014 pengguna internet di Indonesia telah mencapai 82 juta orang. Dan dengan capaian itu Indonesia berada pada peringkat delapan dunia pengguna Internet. Dari jumlah pengguna internet tersebut, 80 persen di antaranya adalah remaja berusia 15-19 tahun (https://kominfo.go.id).

Universitas Dian Nuswantoro atau yang lebih dikenal dengan Udinus adalah salah satu perguruan tinggi swasta di Jawa Tengah yang menurut hasil survey pusat data dan analisa Tempo pada tahun 2013 menjadi menjadi universitas swasta peringkat ketiga se-Indonesia yang menjadi universitas alternatif pilihan utama dimata mahasiswa dan orang tua untuk melanjutkan ke jenjang pendidikan tinggi dibidang Teknologi Informasi. Adanya website atau laman resmi lembaga menjadi salah satu sarana komunikasi bagi Udinus dalam menyampaikan informasi seputar lembaga pendidikan ini kepada stakeholdersnya. Laman merupakan salah satu bentuk teknologi informasi yang dikelola dengan berbagai kestrategisannya.

Ketersediaan informasi melalui laman yang bisa diakses setiap saat oleh stakeholders dalam hal ini mahasiswa, orangtua maupun masyarakat umum merupakan bagian dari kegiatan Public 
Realtions Udinus agar bisa mewujudkan visi misi lembaga yang tujuan akhirnya terkait dengan citra lembaga. Dengan visi menjadi universitas pilihan utama dibidang pendidikan dan kewirausahaan sudah seharusnya pesan yang disampaikan dalam laman udinus menyiratkan hal-hal yang menjadi tujuan lembaga.

Laman yang beralamat di www.dinus.ac.id berisi beragam informasi baik bagi stakeholders internal maupun eksternal yang membacanya. Laman ini terus mengalami pembaharuan baik berita maupun tampilannya. Terakhir pada bulan

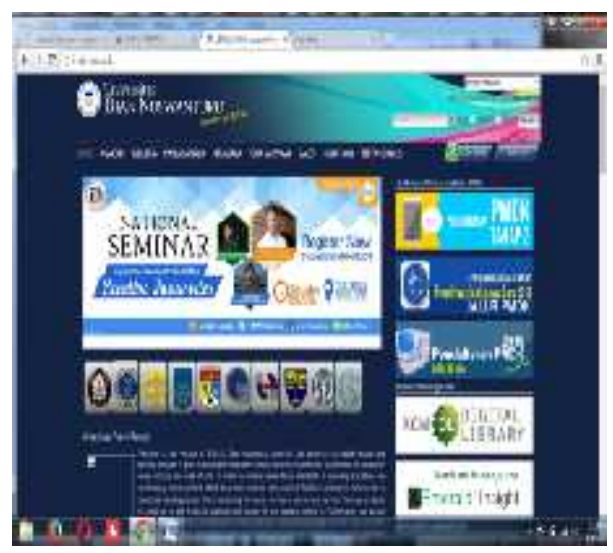

Gambar 1: Contoh Laman Udinus
April tahun 2016 website ini mengalami redesain dengan tetap menonjolkan warna biru yang merupakan identitas corporate, dan terdapat banyak pembaharuan dalam warna, gambar, menu/ jendela yang berbeda dengan laman lama. Laman baru sekilas terlihat lebih menonjolkan gambar-gambar, warna dan font yang lebih besar dan tampilan menu yang lebih variatif.Menu dalam laman ini antara lain informasi untuk calon mahasiswa, mahasiswa, dosen/staf, orang tua, international office, alumni, admisi, berita kampus, program dan tentang udinus.
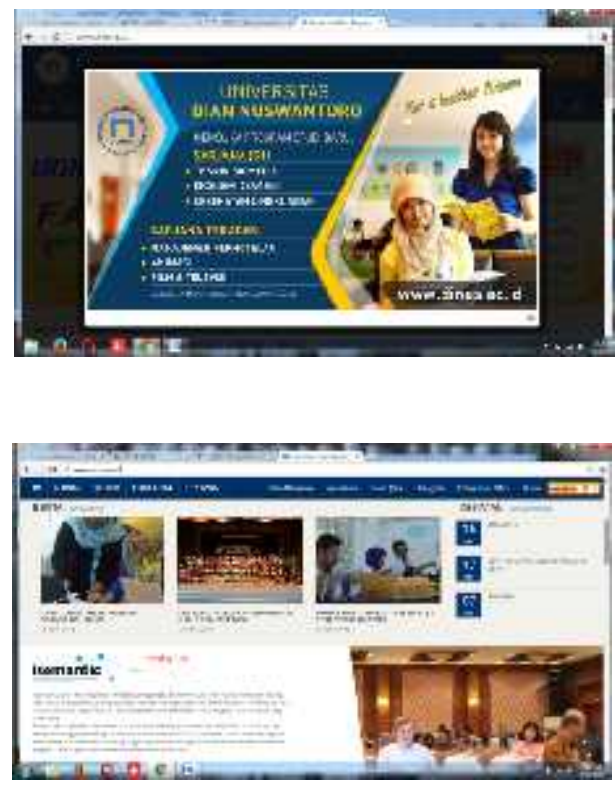

Gambar 2: Contoh Laman Udinus Terbaru

Pada laman yang baru banyak jendela yang ditampilkan dan lebih komplek sehingga harapannya dapat memenuhi harapan dari lembaga ini untuk menyampaikan informasi melalui media ini kepada pihak pihak yang kompeten (stakeholders).

Laman menjadi menarik ingin untuk diangkat dalam sebuah penelitian karena bila ditelisik dari bidang kaji Public Relations, laman adalah salah satu bagian dari Cyber-PR atau E-PR sebagai bagian dari upaya peningkatan reputasi lembaga kepada stakeholder-nya. Universitas Dian Nuswantoro yang bervisi sebagai universitas pilihan utama dibidang pendidikan dan kewirausahaan, melalui lamannya pembaca atau visitor dapat melihat bagaimana informasi yang ditampilkan oleh Udinus sebagai salah satu sarana komunikasi dengan stakeholdersnya. Dan melalui penelitian ini ingin melihat bagaimana pembaca 
laman mempersepsikan pesan tersebut sebagai sebuah informasi.

Reputasi merupakan persepsi terhadap individu atau organisasi, yang mana persepsi tersebut muncul karena kinerja atau kualitas dari individu atau organisasi tersebut (Mitnick dan Mahon, 2007). Brown dan Logsdon menyampaikan bahwa reputasi adalah kumpulan penilaian pihak luar dalam jangka panjang terhadap seberapa baik komitmen perusahaan untuk memenuhi harapan stakeholders (Brown dan Logsdon, 1999).

Desiderato dalam Jalaluddin Rakhmat mengatakan bahwa persepsi adalah pengalaman tentang suatu objek, peristiwa, atau hubungan-hubungan yang diperoleh dengan menyimpulkan informasi dan menafsirkan pesan.
Persepsi dipengaruhi oleh faktor yang bersifat internal maupun yang bersifat eksternal. Faktor internal merupakan faktor yang berkenaan dengan keberadaan individu yang bersangkutan, sementara faktor eksternal adalah faktor pengaruh yang diakibatkan oleh keberadaan rangsangan dari luar (Rakhmat, 2001: 51).

Pada tahun 2012, Puji Indarwati dalam telaahnya tentang Cyber Public Relations Dalam Meningkatkan Citra, melalukan penelitian tentang kegiatan Public Relations terkait dengan laman atau website dengan objek pada Rumah Sakit Islam Klaten.

Berikut ini Penulis ringkaskan penelitian terdahulu yang berkaitan dengan laman dan dunia public relations:

\begin{tabular}{|l|l|l|l|}
\hline No & Nama Penulis & Judul Penelitian & Tahun \\
\hline 1. & Puji Indarwati & $\begin{array}{l}\text { Cyber Public Relations Dalam Meningkatkan Citra (Studi } \\
\text { Kualitatif Kegiatan Cyber PR Melalui Website Rumah Sakit } \\
\text { Islam Klaten Tahun 2011) }\end{array}$ & 2012 \\
\hline 2. & $\begin{array}{l}\text { Anditya Yosephat } \\
\text { Angwarmase }\end{array}$ & $\begin{array}{l}\text { Implementasi Cyber Public Relations Dalam Meningkatkan } \\
\text { Reputasi Universitas Gadjah Mada Yogjakarta Sebagai } \\
\text { Universitas Riset Berkelas Dunia }\end{array}$ & 2014 \\
\hline 3. & Asri Lestari & $\begin{array}{l}\text { Studi Deskriptif Kualitatif Persepsi Visitor Omahsinten.Net } \\
\text { Terhadap Website Omah Sinten Heritage Hotel dan Resto 2012 }\end{array}$ & 2013 \\
\hline 4. & A.J Ibnu Wibowo & $\begin{array}{l}\text { Pengaruh Kualitas Layanan, Reputasi dan Nilai Layanan } \\
\text { Perguruan Tinggi Terhadap Kepuasan Mahasiswa }\end{array}$ & 2009 \\
\hline
\end{tabular}

Sumber: diolah dari berbagai sumber

Pada penelitian ini, Penulis ingin mengamati bagaimana persepsi pembaca laman Udinus terhadap pesan yang ditampilkan pada laman sebagai upaya peningkatan reputasi Udinus sebagai lembaga pendidikan tinggi berbasis teknologi dan entrepreneur dalam membangun komunikasi dengan stakeholders-nya.

Sementara itu, perkembangan teknologi informasi melahirkan beragam media yang oleh sebagian kelompok dinamakan dengan media baru yang berbasis pada perkembangan teknologi internet di ranah kajian Public Realations hal ini dinamakan dengan Cyber-PR. Keberadaan website atau laman pada sebuah instansi sebagai bagian dari upaya peningkatan reputasi. Hal ini terkait dengan salah satu bidang kerja Public Reations Officer sebagai upaya membangun citra perusahaan, dan membangun komunikasi dengan stakeholdersnya. 
Website menurut Hardiman adalah kumpulan halaman di media internet yang berisi informasi dengan topik tertentu. Dan Website adalah bagian dari jenis Cyber-PR. Situs resmi perusahaan biasanya mencerminkan identitas perusahaan itu sendiri dan membangun hubungan dengan publiknya.

Website adalah salah satu aplikasi yang berisikan dokumen-dokumen multimedia (teks, gambar, suara, animasi, video) yang didalamnya yang menggunakan protokol HTTP (hyper text transfer protocol) dan untuk mengaksesnya mengunakan perangkat lunak yang disebut browser. Browser (perambah) adalah aplikasi yang mampu menjalankan dokumen-dokumen web dengan cara diterjemahkan. Prosesnya dilakukan oleh komponen yang terdapat didalam aplikasi browser yang biasa disebut web engine. Semua dokumen web ditampilkan dengan cara diterjemahkan (M. Rudyanto Arief, 2011: 7).

Dalam bidang kerja humas atau public relationsyang berhubungan dengan media online biasa disebut dengan Cyber $P R$. Cyber PR memiliki bentuk yang beragam antara lain:

1. Website (laman) adalah situs resmi yang dapat membantu untuk menjelaskan kepada publik tentang identitas organisasi secara lebih jelas

2. Social network atau jejaring sosial yang mampu menghubungkan semua orang untuk berinteraksi satu dengan lainnya.

3. Intranet yang merupakan jaringan komunikasi internal organisasi untuk menunjang komunikasi publik internal Reputasi perusahaan adalah penjumlahan dari nilai-nilai yang dihubungkan dengan perusahaan didasarkan pada persepsi dan interpretasi mereka dari image yang dikomunikasikan dan perilaku perusahaan secara terus menerus. Hasil evaluasi (penilaian) yang menggambarkan citra perusahaan menurut masyarakat. Reputasi perusahaan adalah kepribadian, identitas dan citra.

Reputasi merupakan persepsi individu yang muncul karena kinerja atau kualitas dari individu atau organisasi tersebut (Mitnick dan Mahon, 2007). Menurut Brown dan Logsdon menyampaikan bahwa reputasi adalah kumpulan penilaian pihak luar dalam jangka panjang terhadap seberapa baik komitmen perusahaan untuk memenuhi harapan stakeholders (Brown dan Logsdon, 1999). Reputasi perusahaan relatif stabil dan bersifat jangka panjang sebagai hasil penilaian kolektif oleh pihak luar terhadap tindakan dan prestasi sebuah perusahaan. Reputasi juga sering didefinisikan sebagai keunggulan kompetitif terpenting yang dimiliki oleh perusahaan (Deephouse, 2000). Reputasi merupakan kumpulan penilaian pihak luar dalam jangka panjang terhadap seberapa baik komitmen perusahaan untuk memenuhi harapan stakeholders (Brown dan Logsdon, 1999).

Persepsi adalah sebuah proses yang didahului oleh penginderaan, yaitu proses dimana diterimanya stimulus oleh individu melalui alat indera. Menurut Julia T. Wood persepsi adalah proses aktif untuk menciptakan makna dengan cara menyeleksi, menyusun, dan menginterpretasi manusia, objek, peristiwa, situasi atau fenomena lainnya. Persepsi terdiri dari 3 proses yaitu: seleksi, organisasi dan interpretasi.

Faktor-Faktor yang mempengaruhi persepsi meliputi factor Fisiologi, Usia, Latar belakang Budaya, Lingkungan Sosial, Peran sosial dalam masyarakat, kompleksitas konitif, kondisi diri sendiri. Budaya adalah keseluruhan nilai, norma, kepercayaan dan pemahaman dari interpretasi terhadap pengalaman yang melingkupi sekelompok manusia. Budaya membentu pola kehidupan dan memandu 
bagimana cara manusia berpikir, merasakan dan berkomunikasi (Wood, 2013: 79).

Komunikasi adalah proses seseorang atau beberapa orang, kelompok, organisasi, dan masyarakat menciptakan, dan menggunakan informasi agar terhubung dan terjalin dengan lingkungan dan orang lain. Proses ini dapat dilakukan secara verbal lewat bahasa lisan maupun tulisan dan secara nonverbal melalui gerak tubuh, ekspresi dan lain sebagianya. Stakeholders didefinisikan sebagai pihak-pihak atau kelompok kelompok yang berkepentingan baik secara langsung maupun tidak langsung terhadap eksistensi atau aktivitas perusahaan dan karenanya kelompok-kelompok tersebut mempengaruhi dan dipengaruhi oleh perusahaan (Wibisono, 2007: 23). Keberadaan stakeholders pada dasarnya dapat mengendalikan atau memiliki kemampuan untuk mempengaruhi pemakaian sumber-sumber ekonomi yang digunakan perusahaan.

Udinus sebagai lembaga yang bergerak di bidang pendidikan dengan visi menjadi universitas pilihan utama dibidang pendidikan dan entrepreneur (kewirausahaan) juga berupaya meningkatkan citra lembaga dengan salah satunya melalui laman di www.dinus.ac.id. Melalui halaman depan laman, pembaca atau visitor dapat melihat bagaimana pesan yang ingin ditampilkan oleh Udinus dan bagaimana mereka mempersepsikan pesan tersebut sebagai sebuah informasi.

Persepsi adalah proses aktif untuk menciptakan makna dengan cara menyeleksi, menyusun dan menginterpretasikan suatu objek, peristiwa situasi dan fenomena lainnya. Persepsi dipengaruhi oleh faktor yang bersifat internal maupun yang bersifat eksternal. Faktor internal merupakan faktor yang berkenaan dengan keberadaan individu yang bersangkutan seperti faktor seleksi atas informasi. Dalam penelitian ini menyeleksi informasi yang dianggap penting. Melihat bagian bagian laman yg menarik dari laman untuk diperhatikan Adanya motivasi dan kebutuhan dari pembaca dalam melihat atau mengakses laman, adanya faktor kebudayaan dari pembaca berupa latar belakang responden, pendidikan dan usia. Faktor eksternal dalam mempersepsi adalah adanya keberadaan rangsangan dari luar seperti lingkungan sekitar.

Dalam penelitian ini hasil yang didapatkan dari persepsi pembaca laman dikaitkan dengan reputasi lembaga sebagai bagian dari sarana komunikasi dengan stakeholdersnya, Penulis mendapatkan informan pembaca laman dari stakeholders internal yang terdiri dari dosen, mahasiswa, pengelola laman dan staff administratif yang terkait laman. Sedangkan informan yang mewakili stakeholders eksternal yaitu pembaca laman yang meliputi alumni,orang tua mahasiswa dan masyarakat umum yang berusia mulai Sembilan belas tahun hingga lima puluh tujuh tahun. Hasil penelitian, Penulis kelompokkan dalam tiga bagian yaitu

1. Laman Sebagai Sarana Pembangunan Reputasi Lembaga di Bidang Pendidikan.

Terkait dengan reputasi, Udinus yang bervisi sebagai universitas pilihan utama dibidang pendidikan dan kewirausahaan berbasiskan teknologi, dari hasil wawancara dengan beberapa informan pembaca laman diketahui bahwa laman udinus sudah mencerminkan sebagai laman lembaga yang bergerak di bidang pendidikan, hal ini terlihat dari pendapat beberapa informan yang menyampaikan bahwa laman udinus menampilkan informasi yang terkait dengan perkuliahan, berita kemahasiswaan, fotofoto kegiatan kampus, jadwal perkuliahan tampilan warna dan atribut visual dan kegiatan akademis lainnya. Hal ini tercermin dari pendapat beberapa informan seperti: 
"...laman udinus mencerminkan lembaga pendidikan, lebih variatif infonya seperti info seminar, mahasiswa berprestasi, kegiatan kemahasiswaan..."

“...laman yang baru juga terdapat penjabaran filosofis dari makna logo udinus ke publik sebagai lembaga pendidikan, terdapat informasi pendaftaran..."

Persepsi ini mucul dari pendapat informan karena adanya motivasi diri dari pembaca dalam mengakses laman udinus terkait dengan pekerjaan mereka, dosen misalnya kebutuhan akan penyampaian materi ajar, penyebaran informasi akademik. Sementara kebutuhan mahasiswa untuk mengakses informasi akademik, dan adanya kebutuhan untuk mendapatkan informasi penerimaan mahasiswa baru terkait dengan masyarakat luas saat mengakses laman udinus mencerminkan sebagai laman yang terkait dengan bidang pendidikan.

2. Laman Sebagai Sarana Pembangunan Reputasi Lembaga di Bidang Kewirausahaan.

Sebagai sebuah lembaga pendidikan, Udinus juga memiliki cita-cita yang tertuang dalam Visi lembaga sebagai lembaga pendidikan pilihan utama yang mencetak sumberdaya manusia di bidang kewirausahaan. Pengimplemetasian visi ini dalam media website/laman menurut informan belum begitu terlihat. Secara umum menurut data dari informan semestinya terlihat dari lulusannya atau alumnus yang mampu membuka usaha sendiri, atau menciptakan peluang usaha. Sementara yang terjadi di laman yang terlihat dari data dua puluh dua testimoni alumnus Udinus yang diunggah di laman, justru banyak dari mereka yang masih berprofesi sebagai karyawan atau menjadi staff suatu instansi baik negeri maupun swasta. Dari data ini menggambarkan bahwa masih banyak alumni yang belum berprofesi sebagai wirausahawan. “...semestinya terlihat dari tresser alumni yang banyak berwirausaha dari yang terpampang di website, sementara sekarang ini yang terlihat belum banyak."

Dari hasil analisa atas testimoni alumnus terpampang ada 22 data alumni yang muncul di website ada 2 nama yang berprofesi sebagai wirausahawan, yaitu pengusaha hijab, dan penulis buku, sementara 20 nama lainnya masih sebagai karyawan atau staff institusi tertentu. Dalam kisah sukses muncul tiga nama seperti Heri Pamungkas, Rusdi dan Sasti Hendri Wibowo yang masing - masih bercerita tentang kisah sukses bekerja pada pimpinan redaksi TVku, Head of dist Channel Internasional Hotel Management School dan dosen Universitas Muhammadiyah Bengkulu.

Selain itu, sebagian besar informan menyatakan kegiatan seperti ekspo wirausaha yang dilakukan oleh mahasiswa mencerminkan tentang aktivitas kewirausahaan. Belum terkelolanya kebaharuan informasi tentang kewirausahaan ini dikarenakan masih terbatasnya sumberdaya manusia yang menanganinya.

3. Laman Sebagai Sarana Pembangunan Reputasi Lembaga di Bidang Teknologi Informasi.

Reputasi merupakan persepsi terhadap seorang individu atau sebuah organisasi, yang mana persepsi tersebut muncul karena kinerja atau kualitas dari individu atau organisasi tersebut (Mitnick dan Mahon, 2007). Brown dan Logsdon menyampaikan bahwa reputasi adalah kumpulan penilaian pihak luar dalam jangka panjang terhadap seberapa baik komitmen perusahaan untuk memenuhi harapan stakeholders (Brown dan Logsdon, 1999). Penyataan ini sesuai dengan apa yang diungkapankan oleh beberapa informan yang menyampaikan bahwa laman atau website Udinus cukup mewakili sebagai lembaga pendidikan yang 
baik dalam bidang teknologi informasinya karena beberapa indikasi yaitu adanya pemutakhiran data atau informasi yang disampaikan ke public atau stakeholders dalam beberapa kegiatannya, menampilkan bentuk informasinya tidak hanya dalam bentuk tulisan tetapi lengkap meliputi gambar, tulisan, video, grafis dan animasinya, teraihnya akreditasi yang baik (A) khususnya bidang teknologi informasi dan sistem informasi, adanya informasi tentang kemenangan mahasiswa dalam Robotic juga mewakili pendapat informan tentang keunggulan teknologi informasi Udinus berdasarkan persepsi pembaca laman yang dimiliki Udinus.

"Website Udinus lebih mewakili reputasi udinus sebagai lembaga pendidikan yang maju di bidang teknologi informasinya, seperti adanya banner,..informasi tentang robotic, game... juga adanya identitas corporate yang berwarna biru dari filosofi warna mewakili konsep teknologi."

Adanya penilaian dari BAN PT yang menyatakan tiga prodi udinus mendapatkan nilai A termasuk didalamnya program studi Teknik Informatika semakin menambah kepercayaan bahwa lembaga udinus bereputasi baik dalam bidang teknologi.

\section{Kesimpulan}

Dalam penelitian ini dapat disimpulkan bahwa sebagai salah satu sarana komunikasi penyebar informasi kepada stakeholders-nya laman udinus cukup mewakili sebagai laman yang bergerak dibidang pendidikan menurut persepsi pembacanya. Secara umum keunggulan ini terlihat dari informasi yang tersaji di laman terkait dengan informasi akademik, kemahasiwaan, alumni, dosen dan kegiatan ilmiah lainnya. Sementara terkait dengan informasi menganai lembaga pendidikan yang berusaha mendidik mahasiswanya sebagai entrepreneur atau wirausahawan laman udinus menurut informan belum mewakili sebagai laman yang berorientasi melahirkan wirausahawan karena informasi seputar wirausahawan, kegiatan yang menyangkut kewirausahaan belum banyak di gali dan di tampilkan. Masih perlu pengelolaan lebih Sementara reputasi Udinus sebagai lembaga yang cukup maju dalam bidang teknologi informasi menurut persepsi pembaca sangat mewakili dengan tampilan laman yang inovatif tidak saja berupa tulisan berita, tetapi di ramu dengan gambar, video, animasi dan selalu meng-update informasinya.

\section{Daftar Pustaka}

Arief, M. Rudyanto. (2011). Pemograman Web Dinamis Menggunakan PHP dan $M y S Q L$. Yogyakarta: Penerbit Andi.

Brown, B. and J. M. Logsdon. (1999). Corporate Reputation and organization ldentity as Constructs for Business and Society Research, in D. Wood and D. Windsor (eds.), Proceeding of the Tenth Annual Meeting of the International Association for Business and Socieg. Paris, France.

Deephouse, D. L. (2000). Media Reputation as a Strategic Resource: An Integration of Mass Communication and Resource-Based Theories. Journal of Management, 26 (6).

Kadir, Abdul. (2003). Pengenalan Sistem Informasi. Yogyakarta: Andi.

Kriyantono, Rachmat. (2009). Teknik Praktis Riset Komunikasi. Jakarta: Penerbit Kencana Prenada

Mitnick, B.M. dan Mahon, J.F. (2007). The 
Concept of Reputational Bliss, Journal of Busrness Ethics, Vol. 72.

Wood, T. Julia (2013). Komunikasi Interpersonal, Interaksi Keseharian. Jakarta: Salemba Humanika.

Puji Indarwati. (2011). Cyber Public Relations Dalam Meningkatkan Citra (Studi Deskriptif Kualitatif Kegiatan Cyber Pr Melalui Website Rumah Sakit Islam Klaten Tahun 2011). Skripsi Program Studi Ilmu Komunikasi, Fakultas Komunikasi dan
Informatika.

Universitas

Muhammadiyah, www.Eprints.Ums.Ac.Id.

Kemkominfo. Pengguna Internet di

Indonesia Capai 82 Juta.

www.kominfo.go.id; diakses Maret 2016.

www.journal.unpar.ac.id/index.php/BinaEko nomi/article/view/718/702; diakses pada tanggal 10 Februari 2016.

www.journal.unpar.ac.id 